\title{
Seventh Day Adventist
}

National Cancer Institute

\section{Source}

National Cancer Institute. Seventh Day Adventist. NCI Thesaurus. Code C103289.

A religious group of Protestant Christians whose beliefs are distinguished by the

observance of Saturday as the Sabbath and by its emphasis on the imminent end of the world and second coming of Jesus Christ. 